\title{
Araștırma Makalesi \\ Turunçgil İhracatı Yapan Firmaların Yapısal Analizi: Antalya İli Örneği
}

\section{ÖZ}

\author{
Ali $\operatorname{TAT}^{1}$, Deniz SARICA ${ }^{1 *}$
}

$\mathrm{Bu}$ çalışmanın amacı, Antalya ilindeki turunçgil ihracatı yapan firmaların genel yapısını, pazarlama sürecini, pazarlama biçimlerini, ihracatını etkileyen faktörleri ve yaşadıkları problemleri ortaya koymaktır. $\mathrm{Bu}$ amaç doğrultusunda Antalya ilinde turunçgil ihracatı yapmakta olan 15 firma ile anket çalışması yapılmıştır. Çalışma sonuçlarına göre, firmaların büyük bir kısmı ihracatlarını karayolu taşımacılığı ile gerçekleştirmektedir. Firmaların turunçgil ihracatında önemli yeri olan ülkeler Belarus Cumhuriyeti, AB ülkeleri, Ukrayna ve Rusya'dır. Araştırmadan elde edilen sonuçlara göre, turunçgil ihracatının belirlenmesinde etkili olan unsurlar müş̧eri istekleri, rakip ülke fiyatları ve firma maliyetleridir. Ayrıca çalışmada, firmaların ürün kaybı, kalite ve yüksek maliyet konusunda ciddi sorunlar yaşadıkları ve verilen devlet desteklerini yetersiz buldukları belirlenmiştir.

Anahtar Kelimeler: Antalya, İhracat, Turunçgil, Pazarlama, Dış Ticaret

\section{Structural Analysis of Citrus Exporting Firms: The Case of Antalya Province}

\begin{abstract}
The study aims to reveal the general structure, marketing process, marketing methods, factors affecting exports and the problems faced by citrus export firms in Antalya province. For this purpose, a survey was conducted with 15 firms exporting citrus fruits in Antalya province by faceto-face interview method. According to the results of the study, most of the firms export by road transport and mostly to the Republic of Belarus, the EU countries, Ukraine and Russia. The factors affecting the determination of citrus exports are customer requests, prices of rival countries, and firm costs. Also, it was determined that the firms were facing serious difficulties in product loss, quality and high cost, and they found the government supports given insufficient.
\end{abstract}

Keywords: Antalya, Export, Citrus, Marketing, Foreign Trade

ORCID ID (Yazar sirasına göre)

0000-0001-8206-4718, 0000-0002-9176-0296

Yayın Kuruluna Geliş Tarihi: 06.04.2021

Kabul Tarihi: 02.05.2021

${ }^{1}$ Isparta Uygulamalı Bilimler Üniversitesi, Ziraat Fakültesi, Tarım Ekonomisi Bölümü, Isparta, Türkiye

*E-posta: denizsarica@isparta.edu.tr 


\section{Turunçgil İhracatı Yapan Firmaların Yapısal Analizi: Antalya İli Örneği}

\section{Giriș}

Anavatanı Güneydoğu Asya olan turunçgiller bilimsel anlamda Citrus türü meyveler içerisinde yer almaktadır. Bu ürünler portakal, limon, greyfurt, mandalina ve nar gibi ekonomik değeri açısından önemli olan türlerin yanı sıra lim, şadok ve bergamot gibi türleri de içerisinde barındırmaktadır. Turunçgiller, C vitamini gibi içeriğinde bulundurdukları zengin elementlerden dolayı insan sağlı̆ına oldukça faydalı besinlerdir. $\mathrm{Bu}$ ürünler yalnızca taze olarak tüketilmek zorunda olmayıp işlenerek gazlı içecek, meyve suyu, reçel ve çeşitli gıdalar için katkı maddeleri olarak da tüketilmektedirler (Atlı ve Söyler, 2018).

Turunçgillerin anavatanı semitropik ve tropik bölgeler olmasına rağmen, Türkiye'de sofralık kalitede olan ürünlerin üretimi en çok subtropik iklim özelliği gösteren Akdeniz Bölgesinde gerçekleşmektedir (Uzun, 2015). Akdeniz Bölgesini, Ege Bölgesi takip etmekte ve az da olsa Marmara ve Karadeniz Bölgeleri'nde de üretimi yapılmaktadır (Uysal ve Palatöz, 2017). 2018 y1lı Gida ve Tarım Örgütü (FAO) verilerine göre dünyada 152.5 milyon ton turunçgil üretimi gerçekleşmiştir (Anonim, 2020a). Bu üretimin \%57'sini portakal, \%23'ünü mandalina, \%11'ini limon, \%4'ünü ise greyfurt olușturmaktadır. Türkiye İstatistik Kurumu (TUIK) verilerine göre Türkiye'de ise 2019 yılında 4.9 milyon ton turunçgil üretimi yapılmış olup bu oran ile Türkiye önemli bir üretici ülke konumunda yer almaktadır. Türkiye'de toplam üretimin \%34.9'u portakal, $\% 29.8$ 'i mandalina, \%19.6's1 limon ve \%5.1'i greyfurttan oluşmaktadır. Turunçgil tüketimi 2018 y1lı verilerine göre 1.8 milyon ton olarak gerçekleşmiştir (Anonim, 2020b). Dünyada turunçgil ihracatı 2019-20 üretim sezonunda 10.1 milyon ton civarındadır. Bunun \%45'lik kısmını portakal, \%27'sini mandalina, \%19'unu limon ve \%9'unu greyfurt olușturmaktadır. 2019-20 üretim sezonunda dünya ihracatında Türkiye mandalinada birinci, limon ve greyfurtta üçüncü ve portakalda beşinci sırada yer almaktadır. Türkiye'de, 2019 yılında turunçgil ihracatı yaklaşık 1.5 milyon ton dolayında gerçekleşmiştir ve bu miktarın \%44'ü mandalina, \%31'i limon, \%16's1 portakal ve $\% 9$ 'su greyfurttur (Aygören, 2020). Antalya ilinde turunçgil üretimine bakıldığında 423400 ton ile en fazla portakal üretilmektedir. Portakalı 130031 tonluk üretim ile nar takip etmektedir. Üçüncü sırada ise limon ve misket limonu yer almaktadır (50 995 ton) (Anonim, 2020b).

Türkiye'nin dünya turunçgil ihracatında önemli bir yere sahip olması nedeniyle, Türk firmalarının uluslararası pazarlara yöneliminde artış görülmektedir. Türkiye genelinde turunçgiller ihracatı yapan yaklaşık 567 firma bulunmakla birlikte bunların \%75'i Akdeniz Bölgesi'nde yer almaktadır. Günümüzde küreselleşmenin oldukça önem kazanmasıyla iç pazarlarda uygulanan stratejilerin diş pazarlara da doğru bir şekilde uygulanması oldukça ciddi bir konudur. Ayrıca bölgede çok sayıda firmanın olması rekabete neden olmaktadır. Üretim kalitesi, tutundurma faaliyetleri ve taşıma şekilleri gibi rekabet edilebilirliği etkileyen unsurların doğru gerçekleştirilmesi firmaların karını olumlu yönde etkilemektedir (Aygören, 2020; Kizıltuğ ve Fidan, 2019). Bu bölgede Antalya'nın turunçgil üretimi açısından oldukça önemli bir yerinin olması ve gelişmiş bir ihracat ağının bulunması araştırma alanının belirlenmesinde etkili olmuştur.

$\mathrm{Bu}$ çalışmada Antalya ilinde, turunçgil ihracatı yapan firmaların genel yapısı, pazarlama süreci, pazarlama biçimleri yaşadıkları problemler ve ihracatı etkileyen faktörleri belirlemek amaçlanmıştır.

\section{Literatür}

Mutlu (2001) çalışmasında, dünyadaki ve Türkiye'deki turunçgil üretiminin ve ihracatının yapısını ve ihracat uygulamalarını incelemiştir. Ayrıca Çukurova bölgesinde turunçgil ihracatı yapan firmaların yapısını ve ilgili sorunlarını araştırmıştır. Çalışmadan elde edilen sonuçlara göre, turunçgil ihracatını etkileyen faktörlerin başında destekleme politikasının geldiği ve ihracatın artırılmasında ürün ve ambalaj kalitesi gibi özelliklerin önemli olduğu vurgulanmıştır.

Paksoy ve ark. (2016), Adana ilinde turunçgiller ihracatı yapan firmaların yapısını, pazarlama şekillerini ve sorunlarını incelemiştir. Çalışmada, firmaların \%75'inin iç pazara da ürün sağladığı ve \%61.7'sinin nakliye için kara yolunu tercih ettiği tespit edilmiştir. 
Ayrıca, firmaların en çok ürün ihraç ettikleri ülkeler sirasıyla Irak, Gürcistan ve Rusya olarak belirlenmiștir. Araştırma kapsamındaki firmaların yaşadığı sorunlar pazar (\%61.7), fiyat düşüklügü $(\% 55.3)$ ve rekabet (\%42.6) sorunudur.

Zenginoğlu (2007) tarafından yapılan çalışmada, Avrupa Birliği’ne (AB) geçiş sürecinde Türkiye turunçgil ihracatının yapısı ve sorunları analiz edilmiştir.

Güven (2010) y1lında Adana ilindeki turunçgil üreten çiftçilerle anket çalışması yaparak pazarlama yapısı ve sorunlarını analiz etmiş ve çözüm önerileri getirmiştir. Çalışmanın sonucunda, şeffaf pazarın ve üretici birliklerinin önemi, taşımacılık alanında soğutucu gemi sayısının artırılması gerektiği, hasada yönelik eğitimlerin sağlanması, yurt içi ve yurt dışı fiyat takip bilgi erişim siteminin geliştirilmesi ve daha uzun bir ihracat sezonunu sağlamak adına ürün deseninin oluşturulması gerektiği konularında tavsiyelerde bulunmuştur.

Oral ve Akpınar (2016), Türkiye'de portakal üreticilerinin üretim ve pazarlama sorunlarını ele almış ve en önemli sorun olan fiyat istikrarsızlığ çekmişlerdir.

Ege ve Caba (2018) çalışmasında, Mersin ilinde Erdemli ilçesinin turunçgil üretimindeki yerini saptayarak, turunçgillerin önemli bir finansman kaynaği olduğunu vurgulamıştır.

Aslan ve ark. (2020), turunçgil sektöründe entegre planlamanın Türkiye'nin rekabetçiliğine etkisini belirlemek ve dinamik bir model geliştirmek amacıyla Mersin ilinde turunçgil ihracatçısı firmalar ile bir anket çalışması yapmışlardır. Araştırmanın sonucunda yatay entegrasyona geçişin paydaşların performansını artıracağı ve entegre bir model ile karlılığın ve rekabet gücünün artacağı tespit edilmiştir.

\section{Materyal ve Yöntem}

$\mathrm{Bu}$ çalışmanın ana materyalini, Antalya ilinde turunçgil ihracatı yapan firmalarla yüz yüze görüşülerek yapılan anketlerden elde edilen birincil veriler oluşturmaktadır. Anket uygulamas1 2020 y1l Mart ayında gerçekleştirilmiştir. Anket yapılacak olan firmaların listesi Batı Akdeniz İhracatçılar
Birliği (BAİB) aracılığı ile elde edilmiş olup zaman ve maddi kısit olmamasi nedeniyle örnekleme aşamasında tam sayım yöntemi uygulanması amaçlanmıştır. Kayıtlı firmaların 69'unun faaliyette olduğu belirlenmiş, ancak bu firmaların 15 tanesi görüşmeyi kabul etmiştir. Anket çalışması, Finike, Kumluca, Konyaaltı, Kepez ve Aksu ilçelerinde gerçekleştirilmiştir. Çalışmanın ikincil kaynaklarını tezler, araştırma raporları benzer makaleler ve istatistik veriler oluşturmuştur. Çalışmadan elde edilen veriler SPSS 26 istatistik paket programı ve MS Excel programı kullanılarak analiz edilmiştir. Verilerin analizi için çizelge ve karşılaştırmalı yorumlarda temel istatistik yöntemlerden yararlanılmıştır.

\section{Bulgular ve Tartışma \\ Firma Yetkilisinin Demografik Özellikleri}

Çalışmada anket uygulanan firma personelinin demografik özellikleri incelenmiş ve elde edilen veriler Çizelge 1'de verilmiştir. Araştırmada anket uygulanan firma personelinin \%66.7'si erkek, \%33.3'ü kadındır. Anket uygulanan firma personelinin \%33.3'ü 18-25 yaş, \%26.7'si 26-33 yaş, \%26.7'si 34-41 yaş ve \%13.3'ü 4249 yaş aralığında yer almaktadır. Katılımcıların \%33.3'ü bekâr, \%66.7'si ise evlidir. Anket uygulanan firma yetkililerinin \%60'1 lisans $\% 20$ 'si lise, \%6.7'si ön lisans ve \%13.3'ü yüksek lisans mezunudur. Araştırma kapsamında anket uygulanan firma yetkilileri arasında ilkokul ve ortaokul mezunu bulunmamaktadır. Paksoy ve ark.'nın 2016 yılında Adana'da yaptıkları çalışmada, kat1lımc1ların \%31.9'u lise mezunu ve \%38.3'ü ilk ve ortaokul mezunudur.

Katılımcıların ișyerlerinde bulundukları pozisyonlarına bakıldığında çoğunluğunu firma yöneticileri (\%33.3) oluşturmaktadır. Katılımciların \%26.7'sinin uzman, \%13.3'ünün firma sahibi, \%6.7'sinin yönetici yardımcısı ve \%6.7'sinin firma ortağ 1 olduğu belirlenmiştir. Araştırmada anket uygulanan firma personelinin firmada çalışma süreleri de incelenmiş olup \%53,4'ü firmada 4-10 y1llık çalışma süresine sahiptir. 
Çizelge 1. Anket uygulanan firma Araştırma kapsamında incelenen firmalara ait personelinin demografik özellikleri

\begin{tabular}{|c|c|c|}
\hline & $\mathbf{n}$ & $\%$ \\
\hline \multicolumn{3}{|l|}{ Cinsiyet } \\
\hline Erkek & 10 & 66.7 \\
\hline Kadın & 5 & 33.3 \\
\hline Toplam & 15 & 100.0 \\
\hline \multicolumn{3}{|l|}{ Yaş } \\
\hline $18-25$ & 5 & 33.3 \\
\hline $26-33$ & 4 & 26.7 \\
\hline $34-41$ & 4 & 26.7 \\
\hline $42-49$ & 2 & 13.3 \\
\hline Toplam & 15 & 100.0 \\
\hline \multicolumn{3}{|l|}{ Medeni hal } \\
\hline Bekâr & 5 & 33.3 \\
\hline Evli & 10 & 66.7 \\
\hline Toplam & 15 & 100.0 \\
\hline \multicolumn{3}{|l|}{ Eğitim durumu } \\
\hline İlkokul & 0 & 0 \\
\hline Ortaokul & 0 & 0 \\
\hline Lise & 3 & 20.0 \\
\hline Ön lisans & 1 & 6.7 \\
\hline Lisans & 9 & 60.0 \\
\hline Yüksek lisans & 2 & 13.3 \\
\hline Doktora & 0 & 0 \\
\hline Toplam & 15 & 100.0 \\
\hline \multicolumn{3}{|l|}{ İşyerindeki pozisyon } \\
\hline Uzman & 4 & 26.7 \\
\hline Yönetici & 5 & 33.3 \\
\hline Yönetici yardımcısı & 1 & 6.7 \\
\hline Firma sahibi & 2 & 13.3 \\
\hline Firma ortağ 1 & 1 & 6.7 \\
\hline Muhasebe & 2 & 13.3 \\
\hline Toplam & 15 & 100.0 \\
\hline \multicolumn{3}{|c|}{ İşyerindeki kıdem (Yıl) } \\
\hline $1-3$ & 5 & 33.3 \\
\hline $4-6$ & 4 & 26.7 \\
\hline $7-10$ & 4 & 26.7 \\
\hline $10+$ & 2 & 13.3 \\
\hline Toplam & 15 & 100.0 \\
\hline
\end{tabular}

Firmalara Ait Genel Bilgiler genel bilgiler Çizelge 2'de verilmiştir. Çalışmada, firmaların ihracat hayatında geçirdikleri süreler ele alındığında, \%33.3'ü 1-3 y11, \%33.3'ü 4-6 y11, \%20'si 7-10 y1l ve $\% 13.3$ 'ü 10 yıldan daha fazla ihracat hayatında bulunduğu görülmüş̧ür.

Çizelge 2. Firmalara ait genel bilgiler

\begin{tabular}{lrr} 
& n & \% \\
\hline Hukuki durumları & & \\
\hline Şahıs şirketi & 1 & 6.7 \\
Anonim şirket & 1 & 6.7 \\
Limited şirket & 13 & 86.7 \\
Kooperatif & 0 & 0 \\
Toplam & 15 & 100.0 \\
\hline Faaliyet alanları* & & \\
\hline Yaş meyve-sebze ihracatı & 15 & 100.0 \\
Depolama & 5 & 33.3 \\
Paketleme & 3 & 20.0 \\
Üretim & 6 & 40.0 \\
Mermer ihracatı & 1 & 6.7 \\
Ambalaj & 1 & 6.7 \\
Plastik kasa üretimi & 2 & 13.3 \\
Zirai ilaç bayi & 1 & 6.7 \\
Komisyonculuk & 2 & 13.3 \\
Balık paketleme & 1 & 6.7 \\
Akaryakıt istasyonu & 1 & 6.7 \\
\hline Çalışan personel sayısı & & \\
\hline İçi & 470 & 73.3 \\
İdari personel & 76 & 11.9 \\
Teknik personel & 64 & 9.9 \\
Yönetici & 31 & 4.8 \\
Toplam & 641 & 100.0 \\
\hline Tesislerin mülkiyet yapısı & & \\
\hline Mülk & 11 & 73.3 \\
Kiralık & 4 & 26.7 \\
Ortaklık & 0 & 0 \\
Diğer & 0 & 0 \\
Toplam & 15 & 100.0 \\
\hline Kendine ait üretim alanı varlığı & \\
\hline Evet & 7 & 46.7 \\
Hayır & 8 & 53.3 \\
Toplam & 15 & 100.0 \\
\hline İhracat hayatında geçirdiği süre (YIl) \\
\hline 1-3 & 5 & 33.3 \\
4-6 & \multicolumn{2}{c}{} \\
\hline & & 33.3 \\
\hline
\end{tabular}




\begin{tabular}{lrr}
\hline $7-10$ & 3 & 20.0 \\
$10+$ & 2 & 13.3 \\
Toplam & 15 & 100.0 \\
\hline
\end{tabular}

*Birden fazla cevap alınmıştır.

Araştırma kapsamında yer alan firmaların \%86.7'si limited şirket, \%6.7'si şahıs şirketi ve \%6.7'si anonim şirket yapısına sahiptir. Firmaların faaliyet alanları incelendiğinde, tamamının yaş meyve-sebze ihracatı yaptı̆̆ tespit edilmiştir. Firmaların \%40'1 üretim, \%33.3'ü depolama ve \%20'si paketleme faaliyetinde bulunmaktadır. Bunların haricinde komisyonculuk, zirai ilaç bayiliği, ambalaj, plastik kasa üretimi gibi birçok diğer sektörlerde de firmaların yer aldığı görülmektedir. Çalışmaya katılan bütün firmaların turunçgil ihracatı yapıyor olmasına rağmen yalnızca ihracata yönelen firma oranı \%13.3'tür. Bu oran işletme içi bölünmenin çok olduğunu, bu nedenle de yeterli düzeyde uzmanlaşmanın olmadığını göstermektedir.

Firma çalışanlarının \%73.3'ü işçilerden oluşmaktadır. İdari personeller çalışanların \%11.9'unu, teknik personeller \%9.9'unu, yöneticiler ise $\% 4.8$ 'ini oluşturmaktadir. Tesislerin mülkiyetleri hakkında firmaların verdiği bilgilere göre, \%73.3'ü kendi mülk arazilerinde faaliyet gösterirken \%26.7'si kiralama yolu ile faaliyetlerini sürdürmektedir. Anket çalışması yapılan firmaların \%46.7'sinin kendine ait bir üretim alanının olduğu, \%53.3'ünün ise kendine ait bir üretim alanının olmadığı belirlenmiştir.

\section{İhracata Yönelik Bilgiler}

Çizelge 3'te araştırma kapsamında anket uygulanan firmaların ihracata yönelik uygulamaları verilmiştir. Araştırmada yer alan firmaların \%93.3'ü ürün işleme aşamalarını kendi tesislerinde gerçekleştirmektedir. Firmaların \%13.3'ü ürünü işlenmiş bir biçimde temin etmekteyken, \%13.3'ü aracı firmalara yaptırmaktadır. Çalışmada ankete katılım sağlayan firmaların \%80'inin ISO sertifikasına, \%53.3'ünün GLOBALGAP sertifikasına ve \%26.7'sinin ise TSE sertifikasına sahip olduğu belirtilmiştir. Ayrıca çalışmaya katılım sağlayan bütün firmalar İhracatçılar Birliği ve Ticaret Odası'na kayıtlıdır. Ticaret Borsası'na kayıtlı olan firmaların oranı ise \%73.3'dür. Firmalar ürün tedarik yöntemleri bakımından incelendiğinde, \%93.3'lük bir kısmı direkt üreticiden ürün temin ederken \%60'1 komisyoncu tarafindan tedarik sağlamakta, $\% 40{ }^{\prime} 1$ ise kendisi üretim yapmaktadır. \%13.3'lük bir kısmı ise tüccardan veya toplayıcıdan ürün temininde bulunmaktadır. Firmaların ürünleri direkt üreticiden temin etmelerinin altında yatan temel neden arac1 maliyetlerini düşürebilmektir. $\mathrm{Bu}$ araştırmada elde edilen sonuca benzer bir şekilde, Zenginoğlu'nun (2007) Türkiye genelinde yaptığ 1 çalışmada firmaların \%83.7'sinin üreticiden temin ettiği sonucuna ulaşılmışıtır.

Firmaların \%73.3'lük bir kısmı dış pazarda doğrudan kendi firmaları olarak temsil edilmektedir. Buna karşın \%33.3'ü ithalatçı firma olarak, \%13.3'ü yurt dışında komisyoncu, \%13.3'ü ise yurt içinde komisyoncu olarak temsil edilmektedir. Katılımciların ihracat yaptıkları ürünler sirasıyla $\% 80$ portakal ve limon, \%66.7 mandalina, \%60 greyfurt ve $\% 53.3$ nardır.

İhracat yapan firmaların \%86.7'si ihracatlarını karayolu taşımacılığı ile gerçekleştirmektedir. Karayolu taşımacılığı ile yapılan ihracatların çoğunluğunun Belarus Cumhuriyeti'ne, AB ülkelerine, Ukrayna'ya ve Rusya'ya yapıldığ 1 saptanmıştır. İkinci sırada ihracat en fazla denizyolu taşımacılığı (\%46.7) ile genellikle uzak doğu ülkeleri ile Hindistan'a yapılmaktadır. Üçüncü sırada ise havayolu (\%26.7) ile yapilan ihracatlar mevcuttur. Havayolu vasitasiyla en fazla Maldiv Cumhuriyeti'ne ürün ihracatı yapılmaktadır. Paksoy ve ark. (2016)'nın çalışmasında, en çok turunçgil ihracatı yapılan ülkeler Irak, Gürcistan ve Rusya; Zenginoğlu (2007)'nun çalışmasında ise $A B$, Balkan ülkeleri ve Rusya'dır. Araştırma alanındaki turunçgil ihracatçılarının mevcut pazarlarını korumak adına yurt dışındaki benzer pazarlara yöneldikleri fakat Singapur, Malezya gibi uzak doğu ülkeleriyle de farklı pazar arayışları içerisinde oldukları anlaşılmaktadır. Çalışmaların hepsinde Rusya'nın ön sıralarda yer alması mesafenin yakın olmasına bağlı olarak düşük maliyetli olmasının ve yapılan olumlu politik yaklaşımların bir etkisi olabileceğini göstermektedir. 
Firmaların \%53.3'ü nakliye esnasında en çok CFR ile yani mal bedeli ve taşıma yolu ile ihracatlarını gerçekleştirmektedirler. \%33.33'ü FOB yani gemi bordasında ürünlerini teslim etme yolu ile ve \%33.3'ü ise EXV yani ticari işletmede teslimat yapmak suretiyle ihracatını gerçekleştirmektedir. \%20'lik bir kısmı ise CFA, CFR ve CPT yöntemlerini kullanmaktadırlar. Ayrıca firmaların \%93.3’ü yani tamamına yakını ürünlerini sigortalatmaktadir.

Çizelge 3. İhracata yönelik bilgiler

\begin{tabular}{|c|c|c|}
\hline & $\mathbf{n}$ & $\%$ \\
\hline \multicolumn{3}{|l|}{ Ürünlerini işleme biçimi* } \\
\hline Kendi tesisinde işliyor & 14 & 93.3 \\
\hline İşlenmiş şekilde alıyor & 2 & 13.3 \\
\hline Aracı firmalara yaptıriyor & 2 & 13.3 \\
\hline \multicolumn{3}{|l|}{ Sahip oldukları sertifikalar* } \\
\hline ISO & 12 & 80.0 \\
\hline TSE & 4 & 26.7 \\
\hline GLOBALGAP & 8 & 53.3 \\
\hline Diğer & 2 & 13.3 \\
\hline \multicolumn{3}{|l|}{ Üye oldukları birlikler* } \\
\hline İhracatçılar Birliği & 15 & 100.0 \\
\hline Ticaret Odas 1 & 15 & 100.0 \\
\hline Ticaret Borsas1 & 11 & 73.3 \\
\hline Diğer & 1 & 6.7 \\
\hline \multicolumn{3}{|c|}{ Ürün tedariki sağladığı yollar* } \\
\hline Kendisi üretiyor & 6 & 40.0 \\
\hline Doğrudan üreticiden alıyor & 14 & 93.3 \\
\hline $\begin{array}{l}\text { Komisyoncu aracılığıyla } \\
\text { alıyor }\end{array}$ & 9 & 60.0 \\
\hline $\begin{array}{l}\text { Tüccardan/toplayıcidan } \\
\text { alıyor }\end{array}$ & 2 & 13.3 \\
\hline \multicolumn{3}{|c|}{ Dış pazarda temsil edilme biçimleri* } \\
\hline Doğrudan kendisi & 11 & 73.3 \\
\hline İthalatçı & 5 & 33.3 \\
\hline Yurt dişında komisyoncu & 2 & 13.3 \\
\hline Yurt içinde komisyoncu & 2 & 13.3 \\
\hline Diğger & 1 & 6.7 \\
\hline \multicolumn{3}{|l|}{ İhraç ettikleri ürünler* } \\
\hline Portakal & 12 & 80.0 \\
\hline Mandalina & 10 & 66.7 \\
\hline Limon & 12 & 80.0 \\
\hline Greyfurt & 9 & 60.0 \\
\hline Nar & 8 & 53.3 \\
\hline \multicolumn{3}{|c|}{ Devlet teşviklerini yeterli bulma } \\
\hline Yete & 4 & 26.7 \\
\hline Yeterli bulmuyor & 11 & 73.3 \\
\hline
\end{tabular}

\begin{tabular}{lrr} 
Toplam & 15 & 100.0 \\
\hline İc piyasaya ürün verme & & \\
\hline Ürün veriyor & 8 & 53.3 \\
Ürün vermiyor & 7 & 46.7 \\
Toplam & 15 & 100.0 \\
\hline
\end{tabular}

\begin{tabular}{lrr}
\hline E-ihracat yapma & & \\
\hline Yapıyor & 4 & 26.7 \\
Yapmiyor & 11 & 73.3 \\
Toplam & 15 & 100.0 \\
\hline Sözleşme yapma durumları & & \\
\hline Yapıor & 12 & 80.0 \\
Yapmiyor & 3 & 20.0 \\
Toplam & 15 & 100.0 \\
\hline
\end{tabular}

\begin{tabular}{lrr}
\hline Sözleşme şekilleri & & \\
\hline Yazılı & 8 & 66.7 \\
Sözlü & 0 & 0 \\
Yazılı ve sözlü & 4 & 33.3 \\
Toplam & 12 & 100.0 \\
\hline \multicolumn{2}{l}{ Pazar bilgisi alma biçimleri* } & \\
\hline Pazardaki temsilci/dağıtıcı & 7 & 46.7 \\
Pazar ülkedeki hükümet ve & 2 & 13.3 \\
endüstri yayınları & 3 & 20.0 \\
Kamu yayınları & 7 & 46.7 \\
İhracatçılar Birliği & 3 & 20.0 \\
İGEME & 12 & 80.0 \\
Kendi pazar araştırmaları & 3 & 20.0 \\
Pazar araştırma firmaları & 4 & 26.7 \\
İnternet &
\end{tabular}

Dış pazar ile ilgili ihtiyaç duyulan bilgiler*

\begin{tabular}{lrr}
\hline Ürün fiyat1 & 10 & 66.7 \\
Ürün talebi & 7 & 46.7 \\
Pazar büyüklüğ̈̈ & 2 & 13.3 \\
Pazar yapısı & 1 & 6.7 \\
Ülke politikaları & 2 & 13.3 \\
Rakip ülke fiyatları & 3 & 20.0 \\
Ürün kalitesi & 3 & 20.0 \\
Firma güvenilirliği & 2 & 13.3 \\
Piyasa rekabet hareketleri & 1 & 6.7 \\
Diş ülke politikaları & 2 & 13.3 \\
Gümrük kanunları & 2 & 13.3 \\
Nakliye bilgileri & 1 & 6.7 \\
*Birden fazla cevap alınmıştır. & &
\end{tabular}

Firmalara ihracat yaptıkları esnada ürünlerin çeşitli nedenlerle geri dönmesi durumunda neler yaptıkları sorulduğunda, firmaların \%40'ının bu ürünleri iç piyasaya sürmekte olduklarını, \%6.7'sinin hale götürdüklerini, \%6.7'sinin 


\section{Turunçgil İhracatı Yapan Firmaların Yapısal Analizi: Antalya İli Örneği}

meyve suyu fabrikalarına gönderdiklerini ve \%53.3'ünün ise imha ettiklerini dile getirmișlerdir. Benzer bir șekilde Paksoy ve ark.'1n (2016) çalışmasında, \%27.6'sı iç piyasaya, $\% 8.5$ 'i hale ve \%55.3'ü imhaya gitmektedir. Firmaların yalnızca \%40'1 kredi kullanırken, \%73.3'ü teşvik ve iadelerden faydalanmaktadır. Bu firmaların \%54.6's1 vergi iadesinden, \%45.5'i vergi muafiyeti - istinas indiriminden, \%45.5' $\mathrm{i}$ DFIF priminden, $\% 18.2$ 'si navlun priminden ve \%9.1'i ihracat kredilerinden faydalanmaktadır.

Firmaların \%73.3'ü devlet desteklerini yeterli bulmadıklarını dile getirmektedir. Ayrıca \%46.7'sinin iç piyasaya ürün vermediği aynı zamanda \%73.3'nün e-ihracat yapmadığı saptanmıștır. Firmaların \%80'i ihracat yaparken sözleşme yaptıklarını ve bunların \%66.7'sinin yazılı olduğu tespit edilmiştir. Hem yazılı hem de sözlü olarak sözleşme yapan firma oranı ise $\% 33.3$ 'tür.

Firmaların \%80'i pazar bilgisini kendi pazar araştırmaları ile elde etmektedir. \%46.7'si İhracatçılar Birliği vasıtasıla, \%46.7'si pazardaki temsilciler vasitasıyla, \%26.7'si ise internet aracılığı ile pazar bilgisi sağlamaktadır. Dış pazar ile ilgili firmaların ihtiyaç duydukları bilgiler ise sirasıyla ürünün piyasa fiyatı (\%66.7), ürünün talebi (\%46.7), ülke politikaları (\%33.3) ve pazar büyüklüğüdür (\%13.3).

Antalya ilinde ankete katılan ihracatçı firmalardan elde edilen verilere göre ürünün kalitesi ve imaj1 (\%93.3), ihracatın yapıldı ğ ülkedeki müşteri istekleri (\%73.3), rakip ülke fiyatları (\%66.7) ve firma maliyetleri (\%66.7) ihracatı etkileyen faktörlerdir. Ayrıca elde edilen sonuçlara göre, ihracatçılar arasında rekabet olduğu ve bu rekabetin genellikle kalite ve fiyat konularında gerçekleştiği tespit edilmiştir. Bu bulgu Kızıltuğ ve Fidan (2019) tarafindan yapılan çalıșmanın sonucu ile benzerlik göstermektedir.

Turunçgil ihracatında firmaların \%66.7'si fiyatları kendileri belirlerken, \%20'si temsilci fiyat önerilerine göre ve \%13.3'ü alıcinın bireysel fiyatlandırmasına göre fiyatlarını belirlemektedir.

Marka kullanımına gelince, stratejik açıdan önemli olan marka kullanımı rekabet ederken firmaların bir adım önde olmasını sağlayan önemli bir unsurdur (Koyuncugil ve Özgülbaş, 2014). Çalışmada yer alan firmaların \%93.3'ü marka kullanmakla birlikte, tamamı firmanın kendi markasını kullanmaktadır. Bu durum Kızıltuğ ve Fidan'ın (2019) çalışmasıyla benzerlik göstermektedir (\%95).

Rekabet edebilirlik açısından bir diğer önemli unsur reklam ve tanitım faaliyetleridir. $\mathrm{Bu}$ faaliyetler internet, televizyon ve fuar gibi çeşitli kaynaklar aracılığıyla yapılabilmektedir. Antalya ilindeki ihracat yapan firmaların \%60'ının reklam ve tanıtım faaliyetleri vardır. Satış artırmada önemli bir unsur olan bu faaliyetlerin $\% 60$ seviyesinde olmasinın en önemli sebebi bu faaliyetlerin masraf olarak görülmesi olabilir. Ayrıca faaliyette bulunan firmaların tamamı doğrudan kendi firmaları aracilığ 1 ile reklam faaliyetlerini gerçekleştirmektedir.

\section{Firmaların Sorunlarına Yönelik Bilgiler}

Araştırma kapsamında anket uygulanan firmalarda karşılaşılan sorunlar ile ilgili bulgular Çizelge 4'te verilmiştir. Firmaların ürün temini konusunda karşılaştıkları sorunların başında (\%80) ürünün iklim koşulları dolayısıyla zarar görmesinden kaynaklanan sorunlar bulunmaktadır. \%66.7'si istenilen kalitede ürün bulamadığından şikâyetçiyken \%46.7'si yeterli miktarda ürün bulamama durumu ile karşı karşıya kalmaktadır.

İncelenen firmalarda ürünlerin nakliyesi ise ihracatta karşılaşılan bir diğer önemli sorundur. Nakliye esnasında yaşanan problemler sırasıyla, ürünün bozulması (\%53.3), nakliye maliyetleri $(\% 46.7)$ ve gümrük problemleridir (\%13.3). Karadeniz ve Özkan (2004) tarafından Antalya ilinde turunçgil ihracatının ele alındı $\breve{g}_{1}$ çalışmada ihracatçıların karşılaştıkları en önemli nakliye sorununun gümrükte bekleme (\%56.2) olduğu tespit edilmiştir.

İhracat esnasında yaşanan sorunlara baktığımızda, firmaların \%40'1 ihraç yapılan ülkedeki rekabet durumundan kaynaklanan problemlerle karşılaşmakta, \%33.3'ü tedarik problemi yaşamakta, \%26.7'si yeterli pazar bulamamakta ve \%20'si fiyat düşüklügünden kaynaklı sorunlar yaşamaktadır. Paksoy ve ark. (2016) yaptıkları çalışmada firmaların en çok 
pazar (\%61.7) sorunu yaşadığını ifade etmişlerdir. $\mathrm{Bu}$ sorunu $\% 55.3$ ile fiyat düşüklügü̈, \%42.6 ile rekabet, \%34 ile gümrük ve $\% 23.4$ ile tedarik sorunu takip etmektedir.

Çizelge 4. Firmaların sorunlarına yönelik bilgiler

\begin{tabular}{|c|c|c|}
\hline & $\mathbf{n}$ & $\%$ \\
\hline \multicolumn{3}{|c|}{$\begin{array}{l}\text { Ürün temini esnasında yaşanan } \\
\text { sorunlar* }\end{array}$} \\
\hline $\begin{array}{l}\text { İstenilen kalitede ürün } \\
\text { bulamama }\end{array}$ & 10 & 66.7 \\
\hline $\begin{array}{l}\text { Yeterli miktarda ürün } \\
\text { bulamama }\end{array}$ & 7 & 46.7 \\
\hline $\begin{array}{l}\text { Ürünün zarar görmesi (İklim } \\
\text { koşulları) }\end{array}$ & 12 & 80.0 \\
\hline Diğer sorunlar & 1 & 6.7 \\
\hline \multicolumn{3}{|c|}{ Ürünün nakliyesinde yaşanan sorunlar* } \\
\hline Ürünün bozulması & 8 & 53.3 \\
\hline Nakliye problemleri & 7 & 46.7 \\
\hline Nakliye maliyetleri & 1 & 6.7 \\
\hline Sigorta ile ilgili sorunlar & 1 & 6.7 \\
\hline Gümrük problemleri & 2 & 13.3 \\
\hline $\begin{array}{l}\text { Termoking (Is1) ayar1 } \\
\text { problemi }\end{array}$ & 1 & 6.7 \\
\hline Kalitesiz ürün & 1 & 6.7 \\
\hline İklim koşulları & 1 & 6.7 \\
\hline Takograf bozulması & 1 & 6.7 \\
\hline Sorun belirtilmemiş & 2 & 13.3 \\
\hline \multicolumn{3}{|c|}{ İhracat aşamasında yaşanan sorunlar* } \\
\hline Tedarik sorunu & 5 & 33.3 \\
\hline Gümrük işlemleri & 2 & 13.3 \\
\hline Fiyat düşüklüğü & 3 & 20.0 \\
\hline Yeterli pazar bulamama & 4 & 26.7 \\
\hline $\begin{array}{l}\text { İhraç yapılan ülkede rekabet } \\
\text { durumu }\end{array}$ & 6 & 40.0 \\
\hline Üreticilerin bilinçsiz olması & 3 & 20.0 \\
\hline \multicolumn{3}{|l|}{ Firmaların genel sorunları* } \\
\hline İşçilik sorunları & 4 & 26.7 \\
\hline Kalite sorunu & 12 & 80.0 \\
\hline Maliyetlerin yüksek olması & 6 & 40.0 \\
\hline Fiyat politikası & 1 & 6.7 \\
\hline Nakliye sorunları & 3 & 20.0 \\
\hline Stoklama imkânı yetersizliği & 2 & 13.3 \\
\hline Yetersiz ürün & 3 & 20.0 \\
\hline $\begin{array}{l}\text { Üreticilerin soğuk hava } \\
\text { depolarında ürün bekletmesi }\end{array}$ & 1 & 6.7 \\
\hline Yeterli pazar bulunamaması & 2 & 13.3 \\
\hline Ürün isleme sorunu & 1 & 6.7 \\
\hline
\end{tabular}

$\begin{array}{lll}\text { Kalitesiz ürün } & 8 & 53.3\end{array}$

Bilinçsiz üretici $\quad 1 \quad 6.7$

$\begin{array}{lll}\text { Düşük rakip ülke fiyatları } & 1 & 6.7\end{array}$

Nakliye esnasinda ürünün $\quad 6 \quad 40.0$

$\begin{array}{lll}\text { bozulmas1 } & & \\ \text { Nakliyenin gecikmesi } & 4 & 26.7\end{array}$

\begin{tabular}{lll} 
Diş ülke politikaları & 3 & 20.0 \\
\hline
\end{tabular}

MRL (Kalınt1) sinırının $\quad 1 \quad 6.7$

$\begin{array}{lll}\text { yüksek olması } & & 6.7 \\ \text { Gümrük işlemleri } & 1 & 6.7\end{array}$

\begin{tabular}{lll} 
Sorun belirtilmemiş & 1 & 6.7 \\
\hline
\end{tabular}

\begin{tabular}{lll}
\hline Firma içi sorunlar* & & \\
\hline Yetersiz personel & 2 & 13.3
\end{tabular}

$\begin{array}{lll}\text { Niteliksiz personel } & 7 & 46.7\end{array}$

Doğru pazar $\quad 2 \quad 13.3$

bulunamamas1

Ürün işleme problemleri $\quad 1 \quad 6.7$

Ürün temini problemleri $\quad 2 \quad 13.3$

$\begin{array}{lll}\text { Finansman sorunu } & 1 & 6.7\end{array}$

$\begin{array}{lll}\text { Teknik aksaklıklar } & 2 & 13.3\end{array}$

$\begin{array}{lll}\text { Yönetim sorunları } & 1 & 6.7\end{array}$

\begin{tabular}{lll} 
Sorun belirtilmemiş & 3 & 20.0 \\
\hline
\end{tabular}

*Birden fazla cevap alınmıştır.

Genel olarak, firmaların \%80'i kalite sorunu, $\% 40$ '1 yüksek maliyet sorunu ve \%26.7'si ise işçilik sorunları ile karşı karşıya kalmaktadır. Turunçgil ihracatında karşılaşılan firma dışı sorunların başında ise, ürünlerin kalitesiz olması gelmektedir (\%53.3). Ayrıca firmaların $\% 40$ '1 da nakliye esnasında ürünün bozulması ile ilgili sorunlar yaşamaktadır. Karşılaşılan firma içi sorunların \%46.7'si personel sorunudur. Bunun yanı sıra, teknik aksaklıklar, yönetim sorunları, yeterli personel bulunamaması gibi birçok sorun mevcuttur.

Firmalarda yaşanan bu sorunlara karş1 firmaların ve devletin alması gereken önlemler şu şekilde sıralanmıştır. Personel eğitimlerinin verilmesi (\%40), ürün kalitelerinin artırılması (\%13.3); ihracat desteklerinin artırılmas1 (\%73.3), üretici desteklerinin artırılmas1 (\%66.7) ve üreticilere etüt veya eğitim verilmesi (\%26.7) şeklinde ifade edilmiştir.

\section{Sonuç ve Öneriler}

Türkiye'nin tarım sektöründe ekonomik açıdan önemli bir üretim faaliyeti olan turunçgiller en çok Akdeniz Bölgesi'nde yetiştirilmektedir. Bu bölgede yer alan Antalya ili de gerek üretim 


\section{Turunçgil İhracatı Yapan Firmaların Yapısal Analizi: Antalya İli Örneği}

gerekse ihracat bakımından oldukça önemli bir yere sahiptir. Özellikle son y1llarda ihracata yönelik turunçgil talebinde artışların meydana gelmesi ve ihracatçı firmaların pazarlama konusunda çeşitli sorunlar yaşaması konunun önemini artırmaktadır. $\mathrm{Bu}$ nedenle, bu çalışmada turunçgil ihracatı yapan firmaların genel yapıs1, pazarlama süreci, pazarlama biçimleri ve yaşadıkları problemler ortaya konulmaya çalışılmıştır. Ayrıca, Antalya ilindeki firmaların ihracatını etkileyen faktörleri tespit etmek amaçlanmıştır. Araştırmada bu unsurların ele alınması firmaların gelişimine katkı sağlamasının yanı sıra ihracat odaklı devlet politikalarının geliştirilmesine de katkı sağlayacağ1 düşünülmektedir. $\mathrm{Bu}$ amaç doğrultusunda Antalya ilinde turunçgil ihracatı yapmakta olan 15 firma ile anket çalışması yapılmıştır.

Araştırmadan elde edilen sonuçlara göre, firmaların tamamının yaş meyve-sebze ihracatı yaptı̆g 1 görülmektedir. Ayrıca firmaların, \%40'1 üretim, \%33.3'ü depolama ve \%20'lik bir kısmı da paketleme faaliyetinde bulunmaktadir. Çalışmada yer alan firmaların tamamı ihracat yapmakla birlikte yalnızca ihracata yönelen firma oranı oldukça düşüktür. $\mathrm{Bu}$ durum uzmanlaşmanın yeterli seviyelerde olmadığının bir göstergesidir.

Çalışma sonuçlarına göre, anket yapılan bütün firmalar İhracatçılar Birliği ve İhracatçılar Odası'na kayıtlıdır ve firmaların \%80'i ISO belgesine sahiptir. Firmaların \%93.3'ünün ürün temininde doğrudan üreticiyi tercih ettiğ görülmüştür. $\mathrm{Bu}$ durum firmaların arac1 maliyetlerini azaltma niyetini göstermektedir.

Firmaların büyük bir kısmı ihracatlarını karayolu taşımacılığ 1 ile gerçekleştirmektedir ve en çok Belarus Cumhuriyeti, $\mathrm{AB}$ ülkeleri, Ukrayna ve Rusya'ya yapmaktadir. Bu bilgi önceki çalışmalarla karşılaştırıldığında, firmaların mevcut durumunu korumak niyetinde olduğunu ve Rusya gibi yakın mesafede olan ülkelerin tercih edilmesinde maliyeti azaltmak niyetinin yattığ düşünülmektedir.

Firmaların \%73.3'ü teşvik ve iadelerden faydalanmaktadır. İncelenen firmaların \%54.6's1 vergi iadesinden faydalandı ğ 1 belirtmiştir. Firmalar verilen devlet desteklerini yeterli bulmamaktadır ve teşviklerin yetersiz olduğunu düşünmektedir. Çalışmada firmalara göre, ihracatın belirlenmesinde etkili olan unsurlar sırasıyla müşteri istekleri, rakip ülke fiyatları ve firma maliyetleridir. Anket uygulanan firmalar ihracatçılar arasında bir kalite $(\% 70)$ ve fiyat (\%70) konusunda rekabet olduğunu dile getirmektedir. Rekabette firmaların bir adım önde olmasını sağlayan marka kullanımı (\%93.3) ise firmalar arasında oldukça yaygındır. Rekabet edebilirlik açısından önemli olan bir diğer unsur ise reklam ve tanıtım faaliyetleridir ve firmaların yalnızca $\% 60$ 'ı bu faaliyetleri uygulamaktadır.

Firmaların ürün temini esnasında öne çıkan sorun ürünün iklim koşullarına bağlı olarak zarar görmesidir. İstenilen kalitede ürünün bulunamaması da ihracatçılar için önemli bir sorundur. İhracat aşamasında firmaların ihraç yapılan ülkedeki rekabet durumundan kaynaklanan problemlerle karşılaştığ belirlenmiştir. Genel olarak değerlendirildiğinde, firmalar kalite ve yüksek maliyet sorunu yaşamaktadır. Firma dışı sorunlar arasında ürünlerin kalitesiz olmas1 başlıca sorunlardan biriyken firma içi sorunlar arasında niteliksiz personel sorunu en önemli sorun olarak görülmektedir.

Sonuç olarak firma düzeyinde ihracatın ve gelirin artışını sağlamak amaciyla İhracatçı Birlikleri gibi kurumlar aracılığ bağlantılar sağlanıp alternatif pazar fırsatları teşvik edilmeli ve bu konuda çözüm sunabilecek politikalar hayata geçirilmelidir. Rekabet edebilirliği ve satış artışını sağlamak amacıyla markalaşma ve reklam gibi faaliyetlere daha fazla önem verilmeli ve ilgili kuruluşlar tarafindan desteklenmelidir. Firmalar için önemli bir sorun olan ürün kaybına çözüm olarak depolama alanlarının iyileştirilmesi ve kapasite artışının sağlanması, uygun donanımlı araçların kullanılması ve hızlı ulaşımın sağlanması gerekmektedir. Ayrıca, sağlanan teşvik ve krediler tatmin edici seviyelerde belirlenmeli, üretici ve ihracat destekleri artırılmalıdır. Firmalarda çalışacak olan personellerin yeterlilikleri için ilgili eğitim programları oluşturulmalıdır. Bununla birlikte, üreticilerin bilgi kaynaklarına daha kolay ulaşabilmesi için yayım hizmetlerinin 
artırılması da bir diğer önemli husustur. Son olarak, gümrük ve nakliye gibi konularda yaşanan sorunları çözmek amacıyla ithalatçı ülke ile işbirliği yapılması faydalı olacaktır.

\section{Kaynaklar}

Anonim, (2020a) Food and agriculture organization of the United Nations (FAO). http://www.fao.org/faostat/en/\# data/QC, Erişim tarihi 21 Haziran 2020.

Anonim, (2020b) Türkiye istatistik kurumu (TUIK). https://biruni.tuik.gov.tr/meda $\mathrm{s} / ? \mathrm{kn}=92$ \&locale $=\mathrm{tr}, \quad$ Erişim tarihi 21 Haziran 2020.

Aslan, H., Zerayak, E., Rad, S. (2020) Modelling of citrus production and export process: Eastern Mediterranean region of Turkey. Karadeniz Uluslararası Bilimsel Dergi 48: 169-187. doi: https://doi.org/10.17498/kden iz.801203.

Atl1, H. F., Söyler, O. (2018) Dünyada ve Türkiye'de turunçgil üretiminin ve ihracatının değerlendirilmesi. Akademik Sosyal Araştırmalar Dergisi 79: 357-366.

Aygören, E. (2020) Turunçgiller ürün raporu 2020. Tepge Yayın No: 324 ISBN: 978605-7599-51-3.

Ege, İ., Caba, N. (2018) Narenciye ihracat1 performansinın tarımsal finansman açıssından incelenmesi : Erdemli örneği. International Journal of Arts and Social Studies 1(1): 43-31.

Güven, N. (2010) Adana ilinde turunçgillerin pazarlama yapısı ve sorunları. Yüksek Lisans Tezi, Çukurova Üniversitesi.

Karadeniz, C. F., Özkan, B. (2004) Antalya ilinde turunçgil meyvelerinin dış satımı ve başlıca sorunların incelenmesi. Türkiye VI. Tarım Ekonomisi Kongresi, 16-18 Eylül 2004, Tokat.

Kizıltuğ, T., Fidan, H. (2019) Hatay ilinin portakal üretimi ve diş ticarette işletmelerin pazarlama stratejileri. $K S \ddot{U}$ Tartm ve Doğa Dergisi 22(2): 281-293. doi: $\quad$ https://doi.org/10.1801 6/ksutarimdoga.vi.464168.

Koyuncugil, A. S., Özgülbaş, N. (2014) 2013 y1lı doğrudan faaliyet destek programı
Hatay ili ihracatı araştırma raporu, Hatay, Nisan 2014, 1-42.

Mutlu, (2001) Çukurova bölgesinde turunçgil ihracat sektör yapısı. Yüksek Lisans Tezi, Çukurova Üniversitesi.

Oral, M., Akpınar, G. (2016) Türkiye'de portakal üreticilerinin üretim ve pazarlama sorunları. XII. Ulusal Tarım Ekonomisi Kongresi, 1: 405-410.

Paksoy, M., Tan, M. G., Bulut, O. D. (2016) Adana ilinde turunçgil ihracatı yapan firmaların pazarlama yapısı ve sorunları. XII. Ulusal Tarım Ekonomisi Kongresi, 2: 1329-1334.

Uysal, O., Palatöz, S. (2017) Dünyada ve Türkiye'de turunçgil üretimi ve diş ticareti. Türkiye Tohumcular Birliği Degisi, 6(22): 4-9.

Uzun, A. (2015) Turunçgil yetiştiriciliği. Gıda, Tarım ve Hayvancılık Bakanlığı, Tarımsal Araştırmalar ve Politikalar Genel Müdürlügüu, Alata Bahçe Kültürleri Araştırma Enstitüsü, Erişim tarihi 21 Haziran 2020. https://arastirma.tarimorman.gov.tr/alata/ Belgeler/Diger-belgeler/Turun\%C3\% A7gilYeti\%C5\%9Ftiricili\%C4\%9FiAUz un.pdf.

Zenginoğlu, A. (2007) AB sürecinde Türkiye turunçgil ihracatının yapısı, ortaya çıkan sorunlar ve çözüm yolları üzerine bir araştırma. Yüksek Lisans Tezi, Ege Üniversitesi. 